\title{
Allele frequency and genotype distribution of aldo keto reductase 1D1 (AKR1D1) rs1872930 genetic variant in a Macedonian population
}

\author{
Aleksandra Kapedanovska Nestorovska ${ }^{1}$, Zorica Naumovska ${ }^{1}$, Krume Jakovski $^{2}$, \\ Zoran Sterjev ${ }^{1}$, Nadica Matevska Geskovska ${ }^{1}$, Aleksandar Dimovski ${ }^{1}$, \\ Ljubica Suturkova ${ }^{1}$ \\ ${ }^{1}$ Center for Biomolecular and Pharmaceutical Analysis, Faculty of Pharmacy, \\ Ss. Cyril and Methodius University, Mother Theresa St. 47, Skopje 1000, Republic of Macedonia \\ ${ }^{2}$ Department of Preclinical and Clinical Pharmacology and Toxicology, Faculty of Medicine, \\ Ss. Cyril and Methodius University, St.50 Division-6 Skopje 1000, Republic of Macedonia
}

Received: September 2018; Accepted: November 2018

\begin{abstract}
AKR1D1 has been recently recognized as novel candidate gene regulating CYP450 coexpression. The AKR1D1 3'-UTR SNP ( rs 1872930) functional genetic variation was considered as important source of phenotypic variation in the activity of CYP450. The minor allele frequency of $r s 1872930$ varies among populations suggesting population specific pharmacogenetic implications. The aim of the present study was to determine the AKR1D1 (rs 1872930) minor allele frequencies and genotypes distribution in a population from Republic of Macedonia. Four hundred and fifty unrelated Macedonian subjects were studied. AKR1D1 variant allele was detected by real time polymerase chain reaction. The distribution of AKR1D $1 * 1 / * 1, * 1 / * 36$ and *36/*36 genotypes was $0.569,0.360$ and 0.071 , respectively. The overall frequency of AKR1D $1 * 36$ variant allele was 0.251 . Our study is the first to assess the frequency distribution of the AKR1D1*36 (rs 1872930) genetic variant in population from Republic of Macedonia and the findings are in accordance with the frequency reported for the Caucasian population.
\end{abstract}

Keywords: AKR1D1, rs1872930, CYP450, variability, gene expression, enzyme activity

\section{Introduction}

Efficacy and safety are the two aspects determining the utility of a therapeutic drug for a treatment of particular disease. The drug metabolizing enzymes and transporters (DMET) are the ultimate molecular determinants of the ADME (absorption, distribution, metabolism and excretion) process (Yu et al., 2016). The cytochrome P450 (P450) monooxygenases are the predominant enzyme system involved in human drug metabolism, accounting for about $75 \%$ of the total reactions for drug metabolism in the human liver, intestine, and kidney (Danielson, 2008; Guengerich, 2008).They can exhibit substantial interindividual variation in basal expression and/or activity ( up to 30- to 40-fold variation for CYP3A enzymes, 50- to 60-fold variation for CYP2B6, and 40- to 50-fold variation for CYP2C9) leading to changes in pharmacokinetics and consequently the pharmacodynamics and differences in the rates of drug elimination and response (Tracy et al., 2016). Apart from variability as a result of drug-drug

\footnotetext{
*alka@ff.ukim.edu.mk
} 
interactions (by P450 induction or inhibition), differences in rates of $\mathrm{P} 450$ mediated drug metabolism among individuals can also be a result of changes in the amino acid sequence of the coding region, genetic variation in promoter regions, variation in transcriptional regulators and alterations in microRNA that affect P450 expression (Yu et al., 2016). Although pharmacogenetic variation associated with changes in the amino acid sequence of the coding region accounts for some of the basal interindividual variation in $\mathrm{P} 450$-mediated metabolism in humans, a large percentage of this variation in $\mathrm{P} 450$ activities remains unexplained by the most common CYP450 cis-variations.

Compared with oxidative CYP450, the role of carbonyl reducing enzymes in the drug metabolism received considerably less attention. In recent years, with the advancement of carbonyl reduction molecular biology, several carbonyl reducing enzymes, grouped into two large protein superfamilies (the aldoketo reductases AKR and short-chain dehydrogenases/reductases - SDR) have been identified and characterized (Chen et al., 2015). Aldo-keto reductases (AKR) are an expanding superfamily of NADPH dependent oxidoreductases that catalyze the reduction of either carbonyl groups to their corresponding alcohols or alfa, beta unsaturated ketones to their corresponding alkonones. Carbonyl reduction of aldehydes, ketones and quinones to their corresponding hydroxyl derivatives plays an important role in the phase I metabolism of many endogenous (biogenic aldehydes, steroids, prostaglandins and reactive lipid peroxidation products) and xenobiotics (pharmacologic drugs, carcinogens, toxicants) compounds (Forrest and Gonzalez, 2000). From the pharmacological point of view, carbonyl reduction has been shown to be of significance not only in various inactivation processes of drugs bearing a carbonyl group but also in activation processes where the resulting carbonyls retain therapeutic potency, thus prolonging the pharmacodynamic effect of the parent drug, or in some instances, a compound gains activity through carbonyl reduction (Malátková and Wsól, 2014). Fifteen AKR members have been identified in humans and most of them belong to AKR1 family (aldehyde reductase AKR1A1; aldose reductase and aldose-like reductase proteins - AKR1B1, AKR1B10 and AKR1B15; the hydroxysteroid dehydrogenases - AKR1C1 to AKR1C4; steroid 5 $\beta$-reductase - AKR1D1; 1,5-anhydro-D-fructose reductase - AKR1E2; the $\beta$-subunits of the potassium voltage gated channels - AKR6A3, AKR6A5, and AKR6A9; and the dimeric aflatoxin aldehyde reductases AKR7A2 and AKR7A3 (Penning, 2015). Human AKR occur in many different tissues such as liver, lung, heart, kidney, brain, ovary and adrenal. They have been implicated in a variety of disease processes (Hoffmann and Maser, 2007). Because of the importance in human health many of AKR enzymes are considered as potential therapeutic targets. AKR1D is a unique subfamily that catalyze a stereospecific irreversible double bond reduction instead of carbonyl reduction (Rizner and Penning, 2013). Recombinant AKR1D1 (3-oxo-5-betasteroid 4-dehydrogenase) was first purified to homogeneity and systematically characterized by Chen et al. (2015). It catalyzes the metabolism of steroid hormones that contain an $\alpha, \beta$-unsaturated ketone in the Aring. Naturally occurring inherited mutations in the AKR1D1 genes can cause serious defects in steroid metabolism leading to disease and suggesting that inherited mutations in other AKRs may account for other disease phenotypes (Penning, 2015). In a recently published study by Chaudry et al. (2013), AKR1D1 has been recognized as novel candidate gene regulating CYP450 coexpression. The authors of this study also identified significant association between a single nucleotide polymorphism (SNP) in AKR1D1 3'untranslated region (UTR) (rs 1872930, T45267C, AKR1D1*36) and higher mRNA expression of AKR1D1 as well as with higher mRNA expression and activity of CYP2B6, CYP2C19, CYP2C8, and CYP3A4, and optioned that AKR1D1*36 genetic variant was predictive for the activity of multiple P450s in the network. The minor allele frequency of rs1872930 varies among populations that could lead to population specific pharmacogenetics implications.

The aim of the present study was to determine the AKR1D1 (rs 1872930) minor allele frequencies and genotypes distribution in a population from Republic of Macedonia.

\section{Material and methods}

\section{Subjects}

Four hundred and fifty unrelated Macedonian subjects (354 males and 96 females; age $45 \pm 6$ years) were enrolled in the study. Of them, $200(44.4 \%)$ were healthy subjects (group A; all male, age $41 \pm 3$ years), volunteers in bioequivalence studies performed at Department of preclinical and clinical toxicology and pharmacology at the Faculty of Medicine, UKIM, Skopje, Republic of Macedonia (RoM) with good health and no signs of any disease (cardiovascular, respiratory, central nervous system, liver and renal) confirmed by physical examination and laboratory tests. The rest 250 subjects (45.6\%) were patients of whom 198 (group B; 71 female and 127 male, age $57 \pm 8$ years) were indicated for clopidogrel treatment because of diagnosed cardiovascular disease (percoutanous coronary intervention - PCI with or without stent; acute coronary syndrome- ACS; myocardial infarction-MI; coronary artery disease - CAD; coronary artery bypass graft-CABG; peripheral arterial diseasePAD; cerebrovascular disease-CVA or multiple atherotrombotic risk factors (Type 1 or 2 diabetes, primary hypercholesterolemia, asymptomatic carotid stenosis)at Special Hospital for Surgery disease "Zan 
Mitrev" in Skopje and 52 patients (group C; 25 female and 27 male, age $36 \pm 12$ years) were on risperidone therapy for treatment of psychiatric disorders at the University Psychiatry Clinic - University hospitals, Skopje, Macedonia. Written informed consent was obtained from all participants. The investigation protocol was approved by Ethics and Scientific committee of the Medical Faculty and performed in accordance with local legislation on clinical research in humans and the Helsinki Declaration, following guidelines of Good Clinical Practice.

\section{Genotyping}

DNA isolation was performed at the Center for Biomolecular Pharmaceutical Analyses, UKIM-Faculty of Pharmacy, Skopje, RoM. For each subject, a 3-ml sample of venous blood was collected in an EDTA tube. The genomic DNA was isolated from the peripheral blood leucocytes using Qiamp DNA Blood kit (Qiagen GmbH, Hilden, Germany) according to the manufacturer's protocol or Proteinase $\mathrm{K}$ digestion/phenol-chloroform extraction and ethanol precipitation. The obtained DNA was spectrophotometrically quantified on Nano Drop $\mathbb{R}$ and purity was verified using 260/280 $\mathrm{nm}$ ratio. DNA integrity was confirmed by $0.8 \%$ agarose electrophoresis, stained with ethidium bromide. All DNA samples were kept at $-20{ }^{\circ} \mathrm{C}$ until further analysis. Genotyping for the AKR1D1*36 (rs1872930, C45267T) variant allele was performed using Real-Time polymerase chain reaction (PCR) with TaqMan SNP genotyping assay (C__1976159_1_) (Applied Bio-systems, Foster City, CA, USA), according to the manufacturer's instructions.

\section{Statistical analysis}

Observed and expected allele and genotype frequencies were compared by means of Hardy-Weinberg equilibrium. Deviations from HWE were evaluated using the Chi-squared test. Fisher exact test was used to determine if the differences in allele frequencies and genotype distribution between the two subject groups (patients and healthy controls) were significant. A P-value $<0.05$ was considered statistically significant.

\section{Results}

The frequencies of the AKR1D1*36 allelic variant and genotypes in the different subgroups of subjects are summarized in Table 1. The observed genotype frequency distribution did not show a significant deviation from the Hardy-Weinberg equilibrium (Chi-squared value and $\mathrm{P}$ were as follows: $3.46^{*} 10^{-6}$ and 0.998 for group A; 0.39 and 0.53 for group B; 1.82 and 0.18 for group C, respectively). No statistically significant differences in genotype distribution and allelic frequencies between the control groups of healthy subjects and any of the patient groups was observed $\left(\mathrm{P}_{\text {Fisher }}\right.$ for group $\mathrm{A}$ vs. $\mathrm{B}=0.793$; group A vs. $\mathrm{C}=0.397$; and group $\mathrm{B}$ vs. $\mathrm{C}=0.474$ ). Since all groups (patients and healthy subjects) showed a similar genotype distribution, the results were integrated for further calculations. AKR1D1*36 genotype distribution in the pooled study sample comprised of 450 subjects were in agreement with Hardy-Weinberg equilibrium (Chi-squared value $=0.825 ; \mathrm{P}=0.363$ ). The frequencies of

Table 1. Allele (A) and genotype (B) frequencies for AKR1D1*36 (rs 1872930) in the study population of healthy controls and patients

\begin{tabular}{clcccc}
\hline \hline \multirow{2}{*}{$\mathrm{A}$} & $\begin{array}{l}\text { AKR1D1*36 } \\
\text { allele }\end{array}$ & \multicolumn{3}{c}{$* 1$} & \multicolumn{2}{c}{$* 36$} \\
\cline { 2 - 5 } & $\mathrm{n}$ & Frequency & $\mathrm{n}$ & Frequency \\
\hline Healthy & $\begin{array}{l}\text { Group A } \\
\text { controls }\end{array}$ & 298 & 0.745 & 102 & 0.255 \\
& $\begin{array}{l}\text { (N=200) } \\
\text { Proup B }\end{array}$ & 301 & 0.760 & 95 & 0.240 \\
$\left(\begin{array}{l}\mathrm{N}=198) \\
\text { Patients }\end{array}\right.$ & $\begin{array}{l}\text { Group C } \\
(\mathrm{N}=52)\end{array}$ & 75 & 0.721 & 29 & 0.279 \\
\hline
\end{tabular}

Group A- healthy volunteers in bioequivalence studies

\begin{tabular}{|c|c|c|c|c|c|c|c|c|c|c|}
\hline \multirow{2}{*}{ B } & \multirow{2}{*}{$\begin{array}{l}\text { AKR1D1*36 } \\
\text { genotype }\end{array}$} & \multicolumn{3}{|c|}{$* 1 / * 1$} & \multicolumn{3}{|c|}{$* 1 / * 36$} & \multicolumn{3}{|c|}{$* 36 / * 36$} \\
\hline & & $\mathrm{n}$ & Observed & Expected & $\mathrm{n}$ & Observed & Expected & $\mathrm{n}$ & Observed & Expected \\
\hline $\begin{array}{l}\text { Healthy } \\
\text { controls }\end{array}$ & $\begin{array}{l}\text { GroupA* } \\
(\mathrm{N}=200)\end{array}$ & 111 & 0.555 & 0.555 & 76 & 0.380 & 0.380 & 13 & 0.065 & 0.065 \\
\hline \multirow{2}{*}{ Patients } & $\begin{array}{l}\text { GroupB }^{\#} \\
(\mathrm{~N}=198)\end{array}$ & 116 & 0.586 & 0.578 & 69 & 0.348 & 0.365 & 13 & 0.066 & 0.057 \\
\hline & $\begin{array}{l}\text { GroupC } \mho \\
(\mathrm{N}=52)\end{array}$ & 29 & 0.558 & 0.520 & 17 & 0.327 & 0.402 & 6 & 0.115 & 0.078 \\
\hline
\end{tabular}

${ }^{\#}$ Group B- patients indicated for clopidogrel treatment because of diagnosed cardiovascular disease

${ }^{v}$ Group C- patients on risperidone therapy for treatment of psychiatric disorders 
the AKR1D1*1/*1,*1/*36 and *36/*36 genotypes were $0.569,0.360$ and 0.071 , respectively. The overall frequency of AKR1D1*36 variant allele in the total study population was estimated at 0.251 (Table 2).

Table 2. Genotype distribution and allelic frequencies of AKR1D1*36 (rs 1872930) genetic variant in a Macedonian population $(\mathrm{N}=450)$

\begin{tabular}{lccc}
\hline \hline AKR1D1*36 & $\mathrm{n}$ & Observed & Expected \\
\cline { 1 - 1 } Genotype & & & \\
\cline { 1 - 1 }$* 1 / * 1$ & 256 & 0.569 & 0.561 \\
$* 1 / * 36$ & 162 & 0.360 & 0.376 \\
$* 36 / * 36$ & 32 & 0.071 & 0.063 \\
Allele & & & \\
$* 1$ & 674 & 0.749 & \\
$* 36$ & 226 & 0.251 & \\
\hline
\end{tabular}

\section{Discussion}

This study was prompted by recent report that identified and validated AKR1D1 as a key regulator of P450 network. According to published data (Chaudhry et al., 2013) over expression of AKR1D1 induced expression of P450s. The common newly identify 3'UTR SNP (rs1872930) was shown to cause perturbation in AKR1D1 mRNA expression that ultimately affects mRNA expression as well as activity of multiple P450s. These findings have been considered as plausible since alterations in AKR1D1 expression (an enzyme critical in both the classic and alternative bile acid synthesis pathways) would be expected to result in altered production of cholic acid and chenodeoxycholic acid, which are not only recognized as fat solubilizers, but also as a signaling hormones with endocrine effects and activators of nuclear hormone receptors, such as pregnane $\mathrm{X}$ receptor (PXR) and constitutive androstane receptor (CAR). Both receptors can be activated by a variety of xenobiotics and exert a xenoprotective function by regulating phase I (CYP3A4, CYP2C9 and CYP2C19) and II detoxification enzymes and transporters (Lee et al., 2009).

AKR1D1 is predominantly expressed in the liver where it is present at least 10-fold higher than in any other tissue which is in agreement with the major biological function of AKR1D1 in bile acid biosynthesis and steroid hormone clearance because both take place in the liver. Expression of AKR1D1 has also been detected in brain, uterus, placenta as well as in testis, colon, skeletal muscle, prostate, lymph node, breast, thyroid, adipose tissue, and blood cells (Langlois et al., 2010). So far, the detailed kinetic mechanism of AKR1D1 has not been fully elucidated. It is known that all AKRs catalyze sequentional ordered bi-bi reaction in which the cofactor binds first and leaves last, raising questions relating to the identity of rate determining step (weather is cofactor binding and release, substrate binding and product release or chemical step) (Chen and Penning, 2014). AKR1D1 accepts various $\mathrm{C} 18-\mathrm{C} 27 \Delta 4-3$-ketosteroids, including sex steroids, glucocorticoids, mineralocorticoids, and bile acid precursors as substrates but it is also assumed that that the double bond reductase activity of AKR1D1 may not be limited only to steroid substrates but also to nonsteroid drug entities.

The AKR1D1 gene is located on chromosome 7, and is in close proximity to the aldose reductases, AKR1B1 and AKR1B10. It is the largest gene in the AKR superfamily consisted of nine exons and eight sizable introns. The mRNA of the gene possesses a long 3'untranslated region containing AT-rich sequences signifying that it may undergo rapid degradation (Charbonneau, 2001; Penning and Drury, 2007). Numerous SNPs, mostly located in 5'- and 3'untranslated regions and introns (SNPs) are reported for AKR1D1. There are 42 non-synonymous mutations in the protein coding region but population datafor minor allelic frequency has not been reported so far. Most of these SNPs have not been functionally characterized (Mindnich and Penning, 2009). There are studies associating several of these polymorphic variants with serious genetic defects, which could lead to neonatal lethal bile acid deficiency and hepatotoxicity (Dury et al., 2010).

According to Chen et al. (2013), the AKR1D1*36 ( $r$ 1872930) is a functional genetic variation which has to be considered as important source of phenotypic variation in the activity of CYP450 by controlling the amount of ligands that activate the previously mentioned P450 transcriptional regulator (PXR and CAR). In line with published data, there is no AKR1D1 coding region SNP in LD to $r s 1872930$. The minor allele frequency of rs 1872930 varies among populations (e.g., Caucasians, 21\%; Chinese, 39\%; Japanese, 23\%; African Americans, 12\%; and Mexicans, 39\%).Taking into account the possibility of population specific pharmacogenetics implications in the P450s mediated drug metabolism, we evaluated the frequency of AKR1D1*36 allelic variant in population from RoM. The observed frequency of AKR1D1*36 in RoM is in agreement with the globally reported frequency for the Caucasian population. To our knowledge, there are no published reports regarding the frequency of this genetic variant in different ethnic groups, so we could not compare the prevalence of $A K R 1 D 1 * 36$ allele and genotypes in the RoM with other European populations.

Furthermore, association between AKR1D1*36 and risk of cardiovascular disease (PCI with or without stent; ACS; MI; CAD; CABG; PAD; CVA or multiple atherotrombotic risk factors) or risk of psychiatric disorders was not observed, suggesting that this SNP cannot be considered as a specific variant for this disease 
states. Consistent with the published literature, we formerly also observed that a considerable percentage of interindividual variation in pharmacokinetics and treatment outcome (efficacy and safety) of ibuprofen, clopidogrel and risperidone (data not shown) cannot be explained by most common CYP450 cis- coding and cis regulatory polymorphisms. In line with this, the obtained data from this study will be used in our further research evaluating whether AKR1D1 (rs1872930) minor allele significantly affects the pharmacokinetics, efficacy and safety of nonsteroidal drugs which are primarily metabolized by CYP2C9, CYP2C19 and CYP2D6 enzymes and used in the treatment of cardiovascular disease and psychiatric disorders.

\section{Conclusion}

Our study is the first to assess the frequency distribution of the $A K R 1 D 1 * 36$ (rs 1872930) genetic variant in population from Republic of Macedonia and the findings are in accordance with the frequency reported for the Caucasian population.

\section{References}

Charbonneau, A., 2001. The V-L. Genomic organization of a human $5 \beta$-reductase and its pseudogene and substrate selectivity of the expressed enzyme. BBA-Gene Struct. Expr. 1517, 228-235. Available at: https://doi.org/10.1016/s0167-4781(00)00278-5.

Chaudhry, A.S., Thirumaran, R.K., Yasuda, K., Yang, X., Fan, Y., Strom, S.C., Schuetz, E.G., 2013. Genetic variation in aldo-keto reductase 1D1 (AKR1D1) affects the expression and activity of multiple cytochrome P450s. Drug Metab. Dispos. 41(8), 1538-1547. Available at: https://doi.org/10.1124/dmd.113.051672.

Chen, M., Penning, T.M., 2014. 5 $\beta$-Reduced steroids and human $\Delta(4)$-3-ketosteroid 5 $\beta$-reductase (AKR1D1). Steroids 83,17-26. Available at: https://doi.org/10.1016/j.steroids.2014.01.013.

Chen, M., Jin,Y., Penning, T.M., 2015. The rate-determining steps of aldo-keto reductases (AKRs), a study on human steroid 5 $\beta$-reductase (AKR1D1). Chem. Biol. Interact. 234, 360-365. Available at: https://doi.org/10.1016/j.cbi.2014.12.004.

Congiu, M., Mashford, M.L., Slavin, J.L., Desmond, P.V., 2009. Coordinate regulation of metabolic enzymes and transporters by nuclear transcription factors in human liver disease. J. Gastroenterol. Hepatol. 24, 1038-1044. Available at: https://doi.org/10.1111/j.1440-1746.2009.05800.x.

Danielson, P.B., 2002. The cytochrome P450 superfamily: biochemistry, evolution and drug metabolism in humans. Curr. Drug Metab. 3(6), 561-597. Available at: https://doi.org/10.2174/1389200023337054.

Drury, J.E., Mindnich, R., PenningM, T.M., 2010. Characterization of disease-related 5betareductase
(AKR1D1) mutations reveals their potential to cause bile acid deficiency. J. Biol. Chem. 285, 24529-24537. Available at: https://doi.org/10.1074/jbc.M110.127779.

Forrest, G.L., Gonzalez, B., 2000. Carbonyl reductase. Chem. Biol. Interact. 129, 21-40. Available at: https://doi.org/10.1016/s0009-2797(00)00196-4.

Guengerich, F.P., 2008. Cytochrome p450 and chemical toxicology. Chem. Res. Toxicol. 21, 70-83. Available at: https://doi.org/10.1021/tx700079z.

Hoffmann, F., Maser, E., 2007. Carbonyl reductases and pluripotent hydroxysteroid dehydrogenases of the shortchain dehydrogenase/reductase superfamily. Drug. Metab. Rev. 39(1), 87-144. Available at: https://doi.org/10.1080/03602530600969440.

Langlois, V.S., Zhang, D., Cooke, G.M., Trudeau, V.L., 2010. Evolution of steroid- $5 \alpha$-reductases and comparison of their function with 5 $\beta$-reductase. Gen. Comp. Endocrinol. 166, 489-497. Available at: https://doi.org/10.1016/j.ygcen.2009.08.004.

Lee, W.H., Lukacik, P., Guo, K., Ugochukwu, E., Kavanagh, K.L., Marsden, B., Oppermann, U., 2009. Structure-activity relationships of human AKR-type oxidoreductases involved in bile acid synthesis: AKR1D1 and AKR1C4. Mol. Cell Endocrinol. 301, 199-204. Available at: https://doi.org/10.1016/j.mce.2008.09.042.

Malátková, P., Wsól, V., 2014. Carbonyl reduction pathways in drug metabolism. Drug Metab. Rev. 46(1), 96-123. Available at: https://doi.org/10.3109/03602532.2013.853078.

Mindnich, R.D., Penning, T.M., 2009. Aldo-keto reductase (AKR) superfamily: genomics and annotation. Hum. Genomics 3(4), 362-370. Available at: https://doi.org/10.1186/1479-7364-3-4-362.

Penning, T.M., Drury, J.E., 2007. Human aldo-keto reductases: Function, gene regulation, and single nucleotide polymorphisms. Arch. Biochem. Biophys. 464, 241-250. Available at: https://doi.org/10.1016/j.abb.2007.04.024.

Penning, T.M., 2015. The aldo-keto reductases (AKRs): Overview. Chem. Biol. Interact. 234, 236-246. Available at: https://doi.org/10.1016/j.cbi.2014.09.024.

Rižner, T.L., Penning, T.M., 2014. Role of aldo-keto reductase family 1 (AKR1) enzymes in human steroid metabolism. Steroids 79, 49-63. Available at: https://doi.org/10.1016/j.steroids.2013.10.012.

Tracy, T.S., Chaudhry, A.S., Prasad, B., Thummel, K.E.,Schuetz, E.G., Zhong ,X.B., Tien, Y.C., Jeong, H., Pan, X., Shireman, L.M., Tay-Sontheimer, J., Lin, Y.S., 2016. Interindividual Variability in Cytochrome P450Mediated Drug Metabolism. Drug Metab. Dispos. 44(3), 343-351. Available at: https://doi.org/10.1124/dmd.115.067900.

$\mathrm{Yu}$, A.M., Ingelman-Sundberg, M., Cherrington, N.J., Aleksunes, L.M., Zanger, U.M., Xie,W., Jeong, H., Morgan, E.T., Turnbaugh, P.J., Klaassen, C.D., Bhatt, A.P., Redinbo, M.R., Hao, P.,Waxman, D.J., Wang, L., Zhong, X.B., 2017. Regulation of drug metabolism and toxicity by multiple factors of genetics, epigenetics, lncRNAs, gut microbiota, and diseases: a meeting report of the 21(st) International Symposium on Microsomes and Drug Oxidations (MDO). Acta Pharm. Sin. B. 7(2), 241-248. Available at: https://doi.org/10.1016/j.apsb.2016.12.006. 


\title{
Алелна фрекфенција и генотипска дистрибуција на алдо кето редуктаза 1 Д1 (АКР1Д1) rs1872930 генетската варијанта во Република Македонија
}

\author{
Александра Капедановска Несторовска ${ }^{1}$, Зорица Наумовска ${ }^{1}$, Круме Јаќовски ${ }^{2}$, \\ Зоран Стерјев ${ }^{1}$, Надица Матевска Гешковска ${ }^{1}$, Александар Димовски ${ }^{1}$, \\ Љубица Шутуркова ${ }^{1}$ \\ ${ }^{1}$ Фармацевтски факултет, Универзитет „,Св. Кирил и Методиј”, ул.Мајка Тереза 47, \\ 1000 Скопје, Р. Македонија \\ ${ }^{2}$ Институт за клиничка и претклиничка фармакологија и токсикоогија, \\ Медицински факултет, Универзитет „,Св. Кирил и Методиј”, ул. 50 Дивизија бр.6, \\ 1000 Скопје, Р. Македонија
}

Клучни зборови: AKR1D1, rs1872930, CYP450, варијабилност, генска експресија, ензимска активност

AKR1D1 неодамна беше препознаен како нов ген кандидат кој ја регулира коекспресијата на CYP450 гените. AKR1D1 3'-UTR еднонуклеотидниот полиморфизам (rs1872930) претставува функционална генетска варијација за која се смета дека претставува значајна причина за фенотипски варијации во активноста на CYР450 ензимската активност. Утврдени се разлики во фреквенција на варијантниот алел помеѓу популациите што имплицира можност за фармакогенетски ефекти. Целта на оваа студија беше да се определи алелната фреквенција и генотипската дистрибуција на AKR1D1*36 (rs1872930) кај популација од Република Македонија. Во студијата се вклучени вкупно четиристотини и педесет испитаници.

AKR1D1*36 (rs1872930) варијантниот алел беше идентификуван со методот на полимераза верижна реакција во реално време. Дистрибуцијата на AKR1D $1 * 1 / * 1$, * $1 / * 36$ и *36/*36 генотиповите изнесува 0,$569 ; 0,360$ и 0,071 , соодветно. Фреквенција на AKR1D1 rs 1872930 минорниот алел изнесува 0,251. Оваа е прва студија во која се утврдува дистрибуцијата на AKR1D1*36 (rs1872930) генетската варијанта во популацијата од Република Македонија и воопшто во популација во Европа при што добиените резултати се во согласност со пријавената фреквенција за белата популација. 